\title{
Enhance Engagement Students Through Kahoot! In Online Lecture During Pandemi Covid-19
}

\author{
Pipih Nurhayati ${ }^{1}$
}

${ }^{1}$ STAI Siliwangi Bandung, Indonesia

CORRESPONDENCE: $\mathbb{M}$ pipih@stai-siliwangi.ac.id

\author{
Article Info \\ Article History \\ Received : 30-07-2021 \\ Revised : 16-08-2021 \\ Accepted : 25-08-2021
}

\section{Keywords:}

Online, Lecture, Kahoot, Engagement

\begin{abstract}
Numerous schools worldwide have closed during Covid-19 pandemic but students has several distraction when they study from home. Schools and universities have to continue with preparing learning method in any occasion like online lecture. Some study results show an increase in linkages using digital applications, one of which is Kahoot. Therefore, this study aims to analyze the acceptance and relationship of students with lectures through Kahoot in online lecture. In this study, 67 students of pre-service Madrasah/ Primary teachers at a Siliwangi Islamic College were chosen as a participant. The age of the students ranged from 19 to 30 years and they were students who were taught by the researcher.

The research conducted of two phases. In the first phases, consist of an introduction, lectures, and Kahoot! Quiz each chapter. In the second phase students answering the questionnaire-based online using google form. Question points in the questionnaire included usability, ease of use, attitude, engagement skills, and interaction. The findings show that a whole respondents agree that Kahoot can improve their learning performance. In spite of encourage in taking a good notes and listening carefully in classroom, Kahoot is contribute students to having fun in the online lecture.
\end{abstract}

\section{Introduction}

As we know, the quickly creating coronavirus emergency is ruling worldwide headlines and adjusting life. Numerous schools worldwide have closed. Schools and universities have to continue with preparing learning method in any occasion, when schools close. The New York Times (30/3/2020) provides an overview of the state of students when studying at home. Students complete school assignments in about 2-3 hours, but for them more tiring than being in school for 8 hours. Some students feel unenthusiastic because they do not have an internet network. Students has several distraction when they study from home. However, students feel more time for reflection and closer to their family. There are several factors for the success of lectures in the classroom. The process of building knowledge will occur well if students are ready to gain knowledge.

Some research has been done mainly to improve the relationship at students with lectures. Some study results show an increase in linkages using digital applications, one of which is Kahoot. However, no deeper analysis has yet been found to improve the relationship of students during lectures at the time with the number of distractions like online Classroom using Kahoot. Therefore, this study aims to analyze the acceptance and relationship of students with lectures through Kahoot! in online lecture.

Several studies referred to Kahoot as a tool to increase student engagement Kahoot being able to provide a fun, competitive, and immersive end to the class and strengthening end to class using gameplay is 
a positive social learning strategy(Cameron \& Bizo, 2019). Overall Kahoot Implementation! quite simple, pleasing aesthetically and inclusive. Kahoot can improve the nature of instructing and learning since decline interruptions in the class (Licorish, Owen, Daniel, \& George, 2018). He uncovered that Kahoot! enhanced the nature of understudy learning in the study hall, with the highest influence reported on classroom dynamics, engagement, motivation and improved learning experience.

Their discoveries additionally propose that the utilization of instructive games in the study hall is probably going to limit interruptions, consequently improving the nature of educating and realizing past what is given in regular study halls. Other factors that contributed to students' enhanced learning,because Kahoot, providing students with timely feedback, and game-play (gamification) strategies.Gamified design is effective in engaged people who were bashful or distracted (Song, Ju, \& Xu, 2017).

Students were motivated, enthusiast and able to manage their time through the questions. The outcomes show that the understudies were progressively persuaded, increasingly excited and ready to deal with their opportunity to think all through the test (Rosdiana, 2019). There was no strained air, and all understudies appeared to be cheerful and energetic in addressing each question.

Survey items

\begin{tabular}{|c|c|c|}
\hline Items & Questions & Scale \\
\hline \multirow[t]{2}{*}{ Demographic } & Gender & Male or female \\
\hline & Age & Age Range \\
\hline \multirow[t]{4}{*}{ Usefulness } & Using Kahoot! improves my learning performance & 5 point Likert \\
\hline & Using Kahoot! increases my learning outcome & 5 point Likert \\
\hline & $\begin{array}{l}\text { Using Kahoot! enhances my desire to produce desired result in my } \\
\text { learning }\end{array}$ & 5 point Likert \\
\hline & Using Kahootlis useful in my learning & 5 point Likert \\
\hline \multirow[t]{4}{*}{ Ease of Use } & I find Kahoot! flexible to be used & 5 point Likert \\
\hline & The Kahoot! functionality and interface is clear and understandable & 5 point Likert \\
\hline & Interacting with Kahoot!does not require a lot of my mental effort & 5 point Likert \\
\hline & Overall, I believe that Kahoot! is easy to use & 5 point Likert \\
\hline \multirow[t]{3}{*}{ Attitude } & I think that using Kahoot! is a good idea & 5 point Likert \\
\hline & I like learning with Kahoot! & 5 point Likert \\
\hline & $\begin{array}{l}\text { I look forward to those aspects of my learning that require the use of } \\
\text { Kahoot! }\end{array}$ & 5 point Likert \\
\hline Skill of & Kahoot! encourage me in: & \\
\hline \multirow[t]{3}{*}{ Engagement } & Taking good notes in online lecture & 5 point Likert \\
\hline & Listening carefully in online lecture & 5 point Likert \\
\hline & Making sure to study on regular basis & 5 point Likert \\
\hline \multirow[t]{5}{*}{ Interaction } & Kahoot! contribute to me in: & \\
\hline & Having fun in the online classroom & 5 point Likert \\
\hline & Participating actively in small-group discussions & 5 point Likert \\
\hline & Helping fellow students & 5 point Likert \\
\hline & Asking questions when I did not understand the lecturer & 5 point Likert \\
\hline
\end{tabular}

\section{Method}

In this study, 67 students of pre-service Madrasah/ Primary teachers at a Siliwangi Islamic College were chosen as a participant. The age of the students ranged from 19 to 30 years and they were students who were taught by the researcher. 


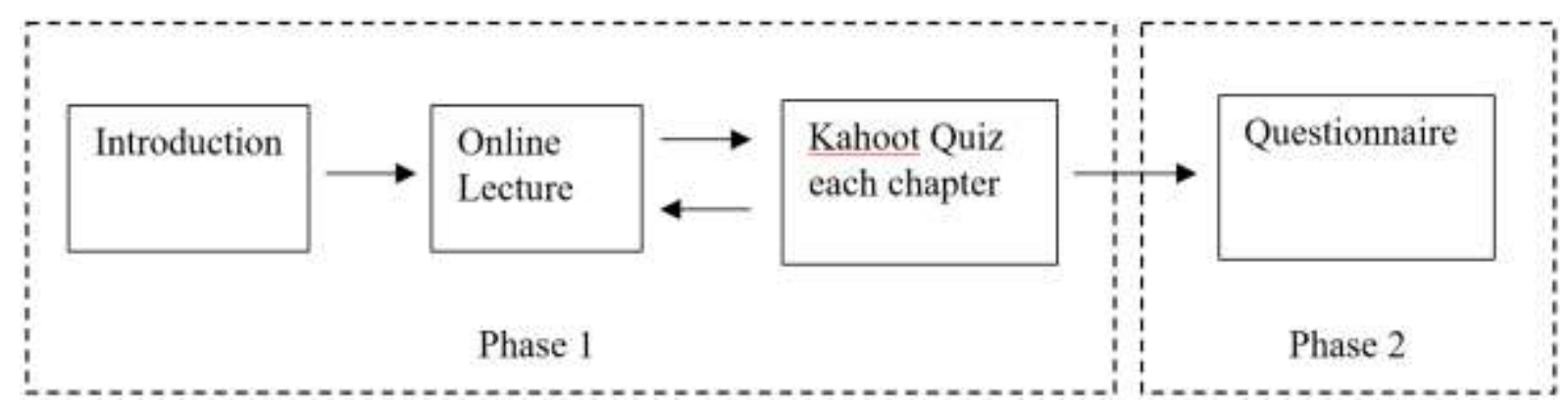

The research conduct of two phases as shown in Figure 1. In the first phases, consist of an introduction, lectures, and Kahoot! Quiz each chapter. In the second phase students answering the questionnaire-based online using google form.

Procedure of the research start from the beginning of the semester. Students were introduced to how to use Kahoot! in their home on their own devices like smartphones. Lessons were conducted based on the lesson plan. After each chapter is completed, a quiz using Kahoot! was held to assess the students understanding. At the end of the chapter, students were asked to fill a five-point Likert Scale questionnaire of 17 questions. All items used a 5-point Likert scale option ranged from 1 (Strongly disagree), 2 (Disagree), 3 (Neutral), 4 (Agree), and 5 (Strongly Agree). The other 2 items covered the demographic data of the students which are gender and age. Then, a focus-group interview was performed with randomly selected 5 students to evaluate their answers in detail. The personal details of the students who responded to the questionnaire and accepted to be interviewed were kept confidential.

The survey instrument was designed to assess students' acceptance of Kahoot! and their engagement in the learning process. Survey instrument design In measuring the students' engagement based on the Gamification Acceptance Model (GAM), a survey instrument to assess students' acceptance of gamification in their learning process based on Student Course Engagement Questionnaire (SCEQ) by Handelsman and the Technology Acceptance Model (TAM) by Davis et al. Questions can be grouped adapted from previous studies by Ab. Rahman, Ahmad, \& Hashim (2018) as were perceived of usefulness (4 items), perceived ease of use (4 items) and attitude towards using gamification technology (3 items). Items contained skill engagement ( 3 items) and participation/interaction engagement (4 items). For measuring students' engagement after the use of certain technology, descriptive statistics used to describe the means, correlations, standard deviations and alphas of the variables as used in the study.

\section{Result and Discussion}

\section{Phase 1}

a. Introduction

Kahoot! is a game-based learning platform that makes it easy to create, share and play learning games or trivia quizzes in minutes. The format and number of questions is up to user. Add videos, images and diagrams to questions to amplify engagement. 


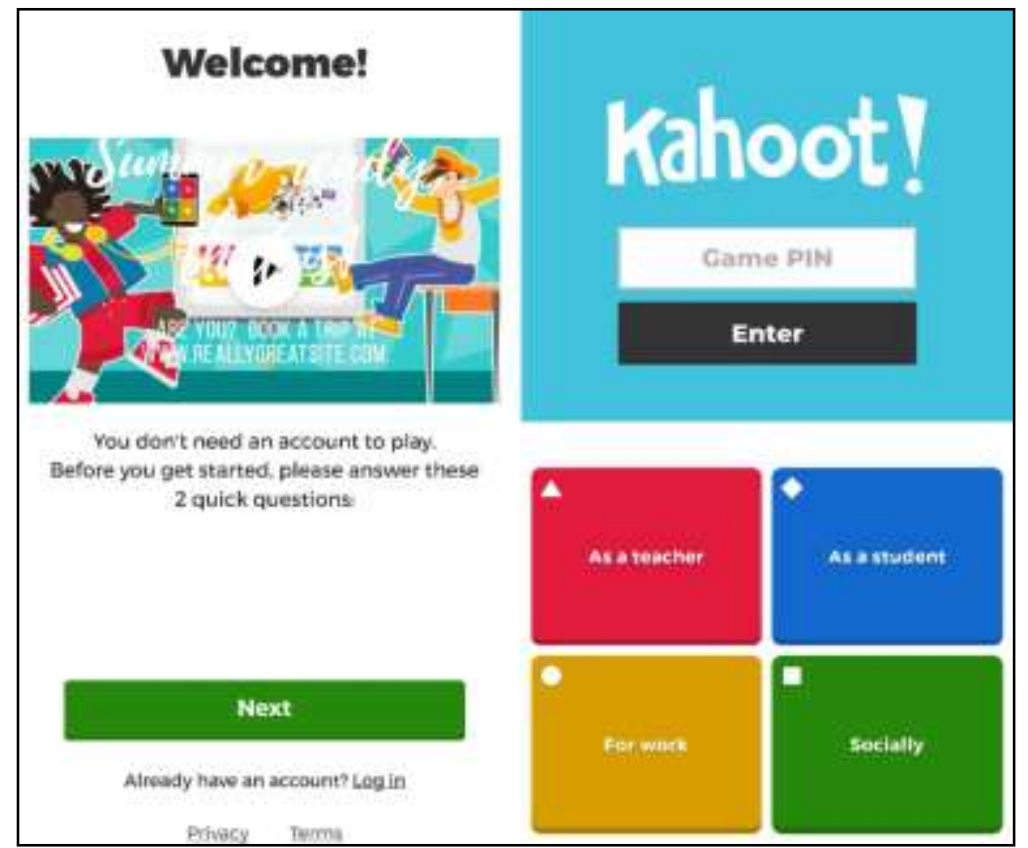

Figure 1 Kahoot installed in the smartphone

Kahoots are best played in a group setting. To join a game need a unique PIN. Lecturer is the game host. Players answer on their own devices, lecturer send kahoot challenges that players complete at their own pace. After a game, encourage players to create and share their own Kahoots.

b. Lecture

In the online lecture process, students enter Google Classroom to get instructions and assignments. The task is in the form of making concept maps. Concept maps will help students find concept definitions and the interrelationships between concepts. In addition, the concept map is able to reveal the students' misconceptions. so that the process of understanding the material will run more directed. 

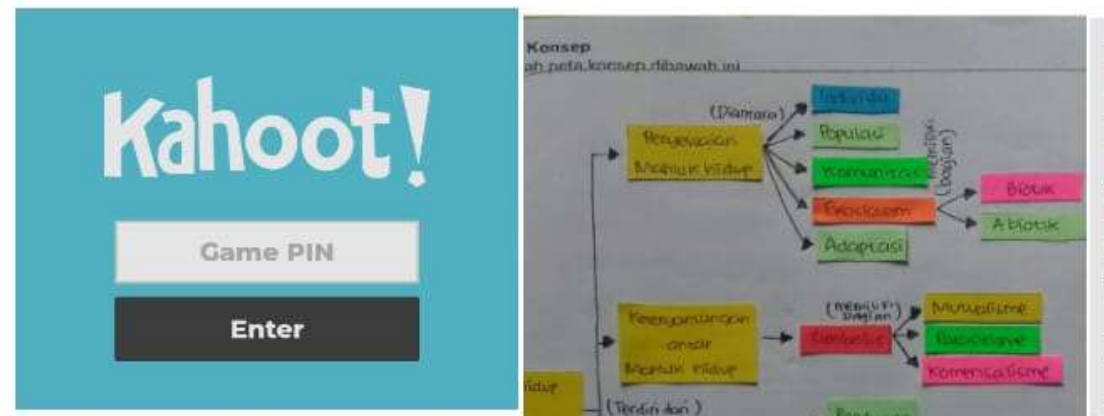

Due yesterday
Kahoot Sistem pada Manusia

100 points

Assalamualaikum,di hari senin yang cerah ini, bgmn kabarnya Class?

Hari ini kita Kahoot dulu yuk..

Ma 2 Quiz, ini thema pertam

Maling

Paling lambat mengisi tgl 2 april

Klik link di bawah atau insert code: 0644923

Teliti dan hati hati ya dalam menjawab.

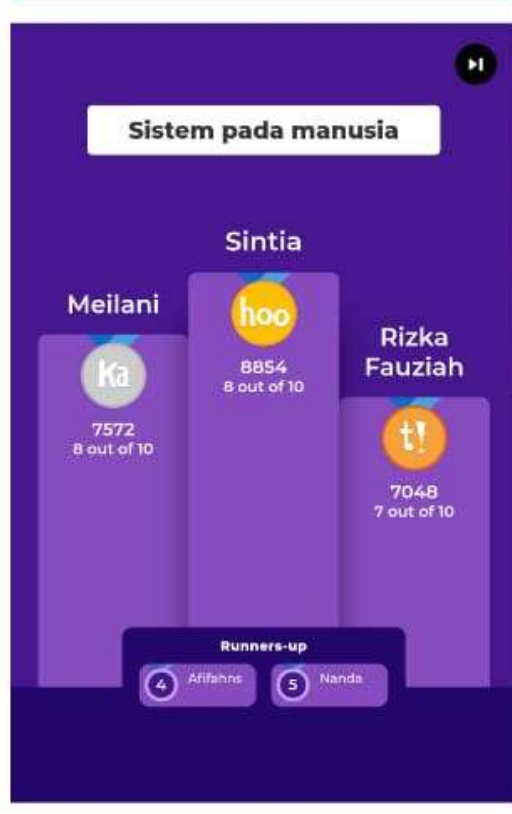

1

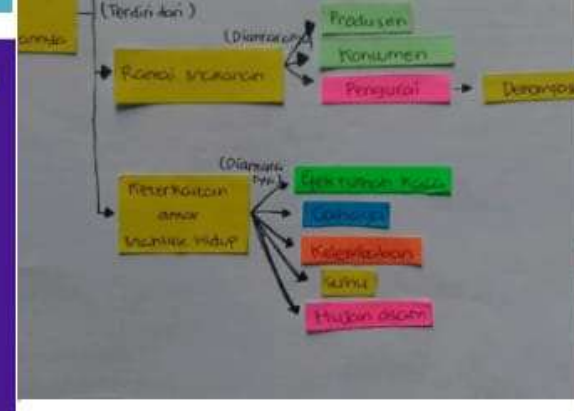

PGMI IV B

PGMI
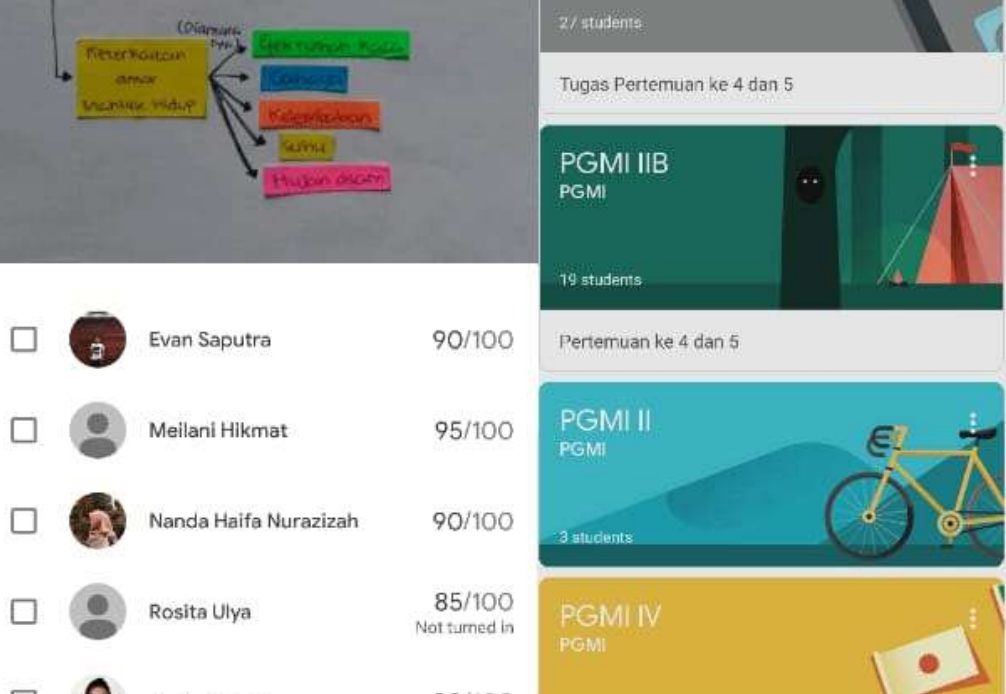

Evan Saputra

$90 / 100$

Pertemuan ke 4 dan 5

Meilani Hikmat

$95 / 100$

\section{PGMIII}

Nanda Haifa Nurazizah

$90 / 100$

PGMi

$85 / 100$

Rosita Ulya

Not turned is

astuders

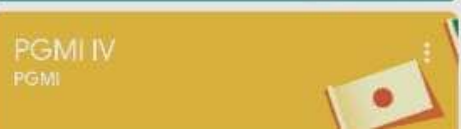

Figure 2 Online Lecture and Kahoot Quiz

c. Quiz each chapter

Quiz using Kahoot is conducted after the lecture process is finished each chapter. The grace period for filling is 3 days. Each question is given 30 seconds. The final point will come out right after students fill in all the questions. At the end a podium will appear for the 3 students with the highest grades.

\section{Phase 2}

A. Demographic analysis

1. Gender and Age

Respondents fill in age and gender questions to find out the distribution of age and sex participants. Table 1 and Figure 1 show the age percentage. Table and Figure showed the gender frequency.

Table 1

Gender Frequency

\begin{tabular}{lllll}
\hline & Frequency & Percent $\%$ & Valid percent & Cumulative percent \\
\hline Male & 11 & 15.7 & 15.7 & 15.7 \\
Female & 59 & 84.3 & 84.3 & 100 \\
\hline Total & 70 & 100 & 100 & \\
\hline
\end{tabular}




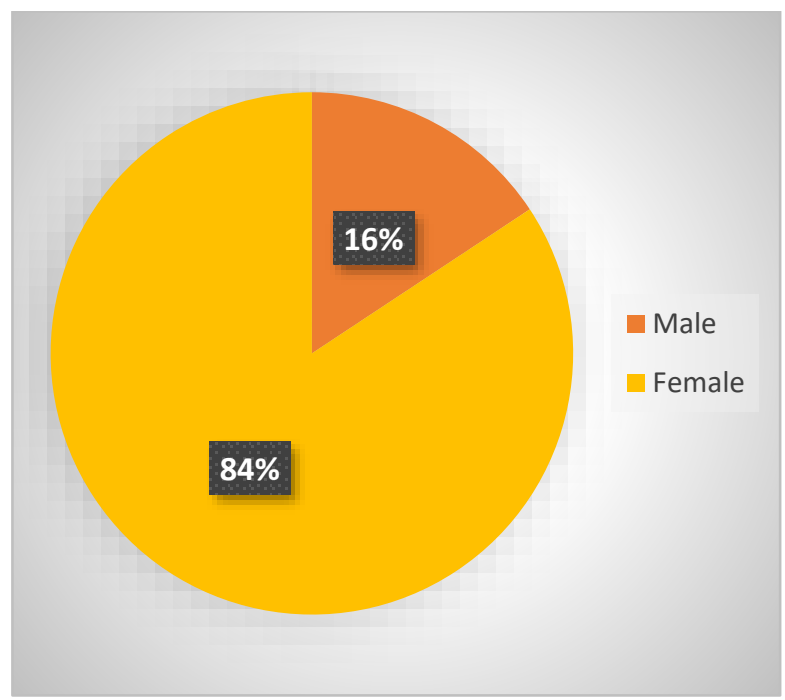

Figure 3.

Gender Frequency

Respondents fill in age and gender questions to find out the distribution of age and sex participants.

Table and Figure show the age percentage. Table and Figure showed the gender frequency.

Table 2

Age Frequency

\begin{tabular}{ccc}
\hline Age & Frequency & Percent $\mathbf{( \% )}$ \\
\hline 19 & 12 & 17,1 \\
20 & 19 & 27,1 \\
21 & 9 & 12,9 \\
22 & 6 & 8,6 \\
23 & 3 & 4,3 \\
24 & 4 & 5,7 \\
25 & 1 & 1,4 \\
26 & 2 & 2,9 \\
27 & 1 & 1,4 \\
28 & 1 & 1,4 \\
29 & 2 & 2,9 \\
30 & 1 & 1,4 \\
31 & 2 & 2,9 \\
32 & 0 & 0,0 \\
33 & 2 & 2,9 \\
34 & 0 & 0,0 \\
35 & 1 & 1,4 \\
36 & 4 & 5,7 \\
\hline Total & $\mathbf{7 0}$ & $\mathbf{1 0 0}$ \\
\hline
\end{tabular}




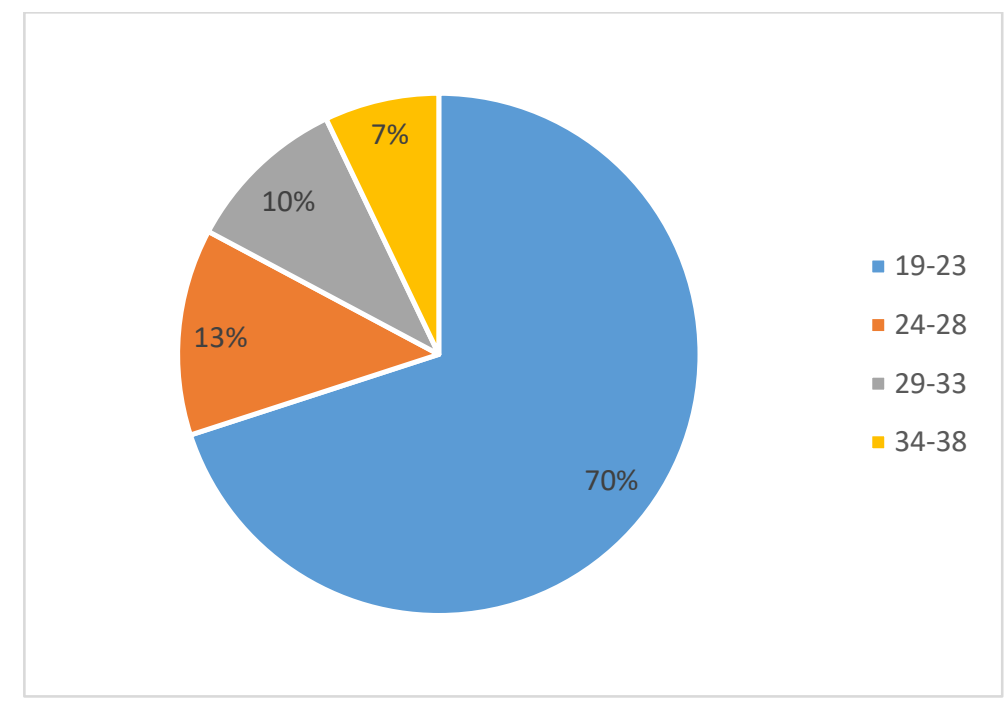

Figure 4

Age Frequency

Table 3

Analysis of preceived usefulness

\begin{tabular}{lr}
\hline & Perceived usefulness \\
\hline Mean & 3.9 \\
Median & 4 \\
Std Deviation & 0.77 \\
Minimum & 1 \\
Maximum & 5 \\
\hline
\end{tabular}

Four questions of perceived usefulness filled by respondents. The descriptive analyze showed on Table 3. Analysis for perceived usefulness variable in Table 3 shows that the distribution of the data was normal. Because the value of mean (3.9) and median (4.0) were close and have low value of standard deviation (0.77). The mean value in Table 3 was 3.90 showed that, most students, the respondents agree on the usefulness of the Kahoot! conducted in this study.

Table 4

Perceived usefulness frequency

\begin{tabular}{|c|c|c|c|c|c|c|c|c|}
\hline \multirow[b]{2}{*}{ Questions } & \multicolumn{4}{|c|}{$\begin{array}{l}\text { Frequency each } \\
\text { questions }\end{array}$} & \multirow{2}{*}{ Total } & \multirow{2}{*}{ Percent } & \multirow{2}{*}{$\begin{array}{l}\text { Valid } \\
\text { percent }\end{array}$} & \multirow{2}{*}{ Cumulative percent } \\
\hline & 1 & 2 & 3 & 4 & & & & \\
\hline Strongly agree & 35 & 26 & 3 & 11 & 75 & 26,8 & 26,8 & 26.8 \\
\hline Agree & 35 & 40 & 39 & 12 & 126 & 45,0 & 45,0 & 71.8 \\
\hline Neutral & 0 & 4 & 28 & 45 & 77 & 27,5 & 27,5 & 99.3 \\
\hline Disagree & 0 & 0 & 0 & 2 & 2 & 0,7 & 0,7 & 100 \\
\hline Total & 70 & 70 & 70 & 70 & 280 & 100 & 100 & \\
\hline
\end{tabular}

Table 4 shown more deeply analyze of the result. Questions number one showed that a whole respondents agree that Kahoot! can improve their learning performance. In where 66 respondents agree that Kahoot increase their learning outcomes, another 4 students neutral with that questions. In where 42 respondents agree Kahoot! enhance their desire in learning, but a half more, 28 respondents neutral with 
that questions. The last question, a half more, 45 respondents not really agree if Kahoot! not useful in their learning.

In where $26.8 \%$ of the respondents strongly agree on usefulness of Kahoot! another $45 \%$ agree. In where $27.5 \%$ neutral and $0.7 \%$ disagree of usefulness Kahoot! This shows that most of students $(71.8 \%)$ respondents agreed using Kahoot! in the classroom.

The findings are in line with the advantages of game based learning, this emerging technology has expanded far beyond integrating digital and online games into learning. Games enable learners to acquire new knowledge and enhance learning through multiple intelligences. There are many online applications/games that could be utilized in teaching and learning. Among the simplest ways to engage students in gamified learning is to try web resources such as Kahoot, Quizlet, Quizziz, Socrative and many more (Hashim, 2018).

Table 5

Analysis of ease to use

Ease to use

Mean

4.2

Median

4

Std Deviation

0.67

Minimum

Maximum

5

Four questions of ease to use filled by respondents. The descriptive analyze showed on Table 5. Analysis for perceived usefulness variable in Table 5 shows that the distribution of the data was normal. Because the value of mean (4.2) and median (4.0) were close and have low value of standard deviation (0.67). The mean value in Table 5 was 4.20 showed that, most students, the respondents agree on the ease to useof the Kahoot! conducted in this study.

Table 6

Perceived ease to use frequency

\begin{tabular}{|c|c|c|c|c|c|c|c|c|}
\hline \multirow[b]{2}{*}{ Questions } & \multicolumn{4}{|c|}{$\begin{array}{l}\text { Frequency each } \\
\text { question }\end{array}$} & \multirow[t]{2}{*}{ Total } & \multirow{2}{*}{ Percent } & \multirow{2}{*}{ Valid percent } & \multirow{2}{*}{ Cumulative percent } \\
\hline & 1 & 2 & 3 & 4 & & & & \\
\hline \multirow{3}{*}{$\begin{array}{l}\text { Strongly Agree } \\
\text { Agree } \\
\text { Neutral }\end{array}$} & 24 & 33 & 11 & 31 & 99 & 35,4 & 35,4 & 35.4 \\
\hline & 38 & 34 & 33 & 35 & 140 & 50,0 & 50,0 & 85.4 \\
\hline & 8 & 3 & 26 & 4 & 41 & 14,6 & 14,6 & 100 \\
\hline Total & 70 & 70 & 70 & 70 & 280 & 100 & 100 & \\
\hline
\end{tabular}

Table 6 shown more deeply analyze of the result. Questions number one showed that a whole respondents agree that Kahoot! was flexible to be use. In where 33 respondents strongly agree and 34 respondents agree that Kahoot! functionality and interface is clear and understandable, another 3 students neutral with that questions. In where 44 (strongly agree and agree) respondents agree that interacting with Kahoot!does not require a lot of their mental effort, but 26 respondents neutral with that questions. The last question, a half more, 66 respondents believe that Kahoot! is easy to use. 
In where $35.4 \%$ of the respondents strongly agree on ease to use of Kahoot! another $50 \%$ agree, and $14.6 \%$ disagree ease to use of Kahoot! This shows that most of students (85.4\%) respondents agreed that Kahoot! ease to use in the classroom.

Some research suggested that following the Kahoot introduction, student retention rates and academic performance increased, and there was a positive correlation between students' scoring highly on the app and achieving higher academic grades. While the app's affordances for learning are promising, the causal relationship between the app usage and improved student outcomes requires further investigation (Pechenkina, Laurence, Oates, Eldridge, \& Hunter, 2017).

Table 7

Analysis for Attitude towards using Kahoot!

\begin{tabular}{lr}
\hline & Attitude \\
\hline Mean & 4.4 \\
Median & 4 \\
Std Deviation & 0.56 \\
Minimum & 3 \\
Maximum & 5
\end{tabular}

Three questions of attitude towards using Kahoot! filled by respondents. The descriptive analyze showed on Table 7. Analysis for attitude variable in Table 7 shows that the distribution of the data was normal. Because the value of mean (4.4) and median (4.0) were close and have low value of standard deviation (0.56). The mean value in Table 7 was 4.40 showed that, most students, the respondents a good attitude towards using Kahoot! conducted in this study.

Table 8

Percieved Attitude towards using Kahoot! frequency

\begin{tabular}{|c|c|c|c|c|c|c|c|}
\hline \multirow[b]{2}{*}{ Strongly Agree } & \multicolumn{3}{|c|}{$\begin{array}{l}\text { Frequency } \\
\text { each question }\end{array}$} & \multirow{2}{*}{$\begin{array}{l}\text { Total } \\
90\end{array}$} & \multirow{2}{*}{$\begin{array}{l}\text { Percent } \\
42,9\end{array}$} & \multirow{2}{*}{$\begin{array}{l}\text { Valid perent } \\
42,9\end{array}$} & \multirow{2}{*}{$\begin{array}{l}\text { Cumulative } \\
\text { percent } \\
42.9\end{array}$} \\
\hline & 19 & 41 & 30 & & & & \\
\hline Agree & 48 & 27 & 37 & 112 & 53.3 & 53.3 & 96.2 \\
\hline Neutral & 3 & 2 & 3 & 8 & 3.8 & 3.8 & 100 \\
\hline Total & 70 & 70 & 70 & 210 & 100 & 100 & \\
\hline
\end{tabular}

Table 8 shown more deeply analyze of the result. Questions number one showed that a whole respondents think agree that using Kahoot! is a good idea. In where 68 (strongly agree and agree) respondents like learning with Kahoot!, another 2 students neutral with that questions. In where 67 respondents look forward to those aspects of their learning that require the use of Kahoot!, 3 respondents neutral with that questions.

In where $42.9 \%$ of the respondents strongly agree on usefulness of Kahoot! another $53.3 \%$ agree, and 3.8\% neutral of usefulness Kahoot! This shows that most of students (96.2\%) respondents agreed using Kahoot! in the classroom. 
Table 9

Analysis for Engagment towards using Kahoot!

\begin{tabular}{lr}
\hline & Engagment \\
\hline Mean & 4.2 \\
Median & 4 \\
Std Deviation & 0.56 \\
Minimum & 3 \\
Maximum & 5 \\
\hline
\end{tabular}

Three questions of percieved engagment towards using Kahoot! filled by respondents. The descriptive analyze showed on Table 9. Analysis for attitude variable in Table 9 shows that the distribution of the data was normal. Because the value of mean (4.2) and median (4.0) were close and have low value of standard deviation (0.56). The mean value in Table 9 was 4.20 showed that, most students, the respondents a good attitude towards using Kahoot! conducted in this study.

Table 10

Percieved Engagment towards using Kahoot! frequency

\begin{tabular}{|c|c|c|c|c|c|c|c|}
\hline \multirow[b]{2}{*}{ Strongly Agree } & \multicolumn{3}{|c|}{$\begin{array}{l}\text { Frequency } \\
\text { each } \\
\text { question }\end{array}$} & \multirow{2}{*}{$\begin{array}{l}\text { Frequency } \\
54\end{array}$} & \multirow{2}{*}{$\begin{array}{l}\text { Percent } \\
25,71\end{array}$} & \multirow{2}{*}{$\begin{array}{l}\text { Valid perent } \\
25,71\end{array}$} & \multirow{2}{*}{$\begin{array}{l}\text { Cumulative percent } \\
25.71\end{array}$} \\
\hline & 12 & 21 & 21 & & & & \\
\hline Agree & 52 & 46 & 47 & 145 & 69,05 & 69,05 & 94.76 \\
\hline Neutral & 6 & 3 & 2 & 11 & 5,238 & 5,238 & 100 \\
\hline Total & 70 & 70 & 70 & 210 & 100 & 100 & \\
\hline
\end{tabular}

Table 10 shown more deeply analyze of the result. Questions number one showed that a whole respondents encourage in taking a good notes in classroom. In where 67 (strongly agree and agree) respondents encourage to listening carefully in classroom, another 3 students neutral with that questions. In where 68 respondents agree that Kahoot encourage students to make sure study on regular basis.

In where $25.71 \%$ of the respondents strongly agree on skill if engagement of Kahoot! another $69.05 \%$ agree, and $5.23 \%$ neutral of that question. This shows that most of students $(94.76 \%)$ respondents agreed using Kahoot! in the classroom with its skill of engagement.

Technology is being increasingly integrated into teaching environments in view of enhancing students' engagement and motivation. In particular, game-based student response systems have been found to foster students' engagement, enhance classroom dynamics and improve overall students' learning experience. Educational games in the classroom is likely to minimise distractions, thereby improving the quality of teaching and learning beyond what is provided in conventional classrooms (Licorish et al., 2018). Other factors that contributed to students' enhanced learning included the creation and integration of appropriate content in Kahoot!, providing students with timely feedback, and game-play (gamification) strategies. 
Table 11

Analysis for Students interactions towards using Kahoot!

\begin{tabular}{lr}
\hline & Interactions \\
\hline Mean & 4.4 \\
Median & 4 \\
Std Deviation & 0.58 \\
Minimum & 3 \\
Maximum & 5 \\
\hline
\end{tabular}

Four questions of interactions towards using Kahoot! filled by respondents. The descriptive analyze showed on Table 11. Analysis for attitude variable in Table 11 shows that the distribution of the data was normal. Because the value of mean (4.4) and median (4.0) were close and have low value of standard deviation (0.58). The mean value in Table 11 was 4.40 showed that, most students, the respondents a good interacting towards using Kahoot! conducted in this study.

Table 12

Percieved Students interaction towards using Kahoot! frequency

\begin{tabular}{l|r|r|r|r|llll}
\hline & \multicolumn{9}{|l}{ Frequency each } & & & & & Frequency \\
& question & Percent & Valid perent & $\begin{array}{l}\text { Cumulative } \\
\text { percent }\end{array}$ \\
\hline $\begin{array}{l}\text { Strongly } \\
\text { Agree }\end{array}$ & 27 & 33 & 32 & 22 & 114 & 40,7 & 40,7 & 40.7 \\
Agree & 41 & 34 & 34 & 41 & 150 & 53,6 & 53,6 & 94.3 \\
\cline { 2 - 9 } Neutral & 2 & 3 & 4 & 7 & 16 & 5,7 & 5,7 & 100 \\
\hline Total & 70 & 70 & 70 & 70 & 280 & 100 & 100 & \\
\hline
\end{tabular}

Table 12 shown more deeply analyze of the result. Questions number one showed that a whole respondents think agree that using Kahoot! is contribute students to having fun in the online lecture. In where 68 (strongly agree and agree) respondents like learning with Kahoot!, another 2 students neutral with that questions. In where 67 respondents look forward to those aspects of their learning that require the use of Kahoot!, 3 respondents neutral with that questions.

In where $40,7 \%$ of the respondents strongly agree on usefulness of Kahoot! another $53,6 \%$ agree, and 5,7\% neutral of usefulness Kahoot! This shows that most of students (96.2\%) respondents agreed using Kahoot! in the classroom.

Above all, due to the unique characteristics of the new generation of learners, teachers could not run away from integrating and applying technology in teaching and learning. For these learners, technology is not considered an accessory to life but is viewed as a way of life. This has implications on pedagogy and it demands the transformation of education (Hashim, 2018)

\section{Conclusion}

In the pandemic situation teachers could not run away from integrating and applying technology in teaching and learning. The use of Kahoot in the online classroom is minimize distractions, thereby improving the quality of online lecture. The findings show that a whole respondents agree that Kahoot can improve their learning performance. In spite of encourage in taking a good notes and listening carefully in classroom, Kahoot is contribute students to having fun in the online lecture. Obstacles felt by students 
during the implementation of Kahoot in lectures such as signals and accuracy of students in choosing answers because of the short time to answer. For further research to prevent students from feeling bored, it is recommended to try to integrate with other applications.

\section{References}

Ab. Rahman, R., Ahmad, S., \& Hashim, U. R. (2018). The effectiveness of gamification technique for higher education students engagement in polytechnic Muadzam Shah Pahang, Malaysia. International Journal of Educational Technology in Higher Education, 15(1). https://doi.org/10.1186/s41239-018-0123-0

Cameron, K. E., \& Bizo, L. A. (2019). Use of the game-based learning platform KAHOOT! to facilitate learner engagement in animal science students. Research in Learning Technology, 27(1063519), 1-14. https://doi.org/10.25304/rlt.v27.2225

Hashim, H. (2018). Application of Technology in the Digital Era Education. International Journal of Research in Counseling and Education, 1(2), 1. https://doi.org/10.24036/002za0002

Licorish, S. A., Owen, H. E., Daniel, B., \& George, J. L. (2018). Students' perception of Kahoot!'s influence on teaching and learning. Research and Practice in Technology Enhanced Learning, 13(1). https://doi.org/10.1186/s41039-018-0078-8

Pechenkina, E., Laurence, D., Oates, G., Eldridge, D., \& Hunter, D. (2017). Using a gamified mobile app to increase student engagement, retention and academic achievement. International Journal of Educational Technology in Higher Education, 14(1). https://doi.org/10.1186/s41239-017-0069-7

Rosdiana, L. A. (2019). Students' Responses Toward Kahoot Application in Indonesian Subject. Alinea: Jurnal Babasa, Sastra, Dan Pengajaran, 2(1), 1. https://doi.org/10.35194/alinea.v2i1.519

Song, D., Ju, P., \& Xu, H. (2017). Engaged cohorts: Can gamification engage all college students in class? Eurasia Journal of Mathematics, Science and Technology Education, 13(7), 3723-3734. https://doi.org/10.12973/eurasia.2017.00755a 